\title{
Effects of Metallic Iron Bearing Resources on Iron Ore Sintering
}

\author{
Masanori NAKANO, Takuji YAMAKAWA, ${ }^{1)}$ Naoki HAYAKAWA ${ }^{1)}$ and Morio NAGABUCHI") \\ Process Technology Research Laboratories, Nippon Steel Corporation, Shintomi, Futtsu, Chiba-ken, 293 Japan. \\ 1) Iron Making Division, Nakayama Steel Works Ltd., Funamachi, Taisho-ku, Osaka, Osaka-fu, 593 Japan.
}

(Received on June 25, 1997; accepted in final form on August 22, 1997)

\begin{abstract}
In order to clarify the effects of the use of resources containing metallic iron (MIRs) on the sintering process, plant tests have been conducted at Nakayama Steel. With an increase in MIRs, the following results were observed:

(1) Sinter yield and productivity deteriorated

(2) Emissions of $\mathrm{NO}_{x}$ and $\mathrm{SO}_{x}$ were reduced

(3) Sinter qualities changed depending on the kind of MIR

Pressure measurements of the sinter bed and CT observations of sintercake revealed that a decrease in porosity in the lower part of sintercake caused a decrease in permeability of the bed and an increase in the volume of an unsintered portion near the hearth layer. A decrease in fuel nitrogen and sulfur inputs in the sinter mix, which was caused by substituting metallic iron for coke breeze, reduced the emissions of $\mathrm{NO}_{x}$ and $\mathrm{SO}_{x}$.
\end{abstract}

KEY WORDS: agglomeration; metallic iron resource; permeability; productivity; sintering; $\mathrm{NO}_{x} ; \mathrm{SO}_{x}$.

\section{Introduction}

In order to promote the recycling of $\operatorname{scrap}^{1)}$ and mill scale as inexpensive raw materials, use of large amounts of metallic-iron bearing resources (MIRs) was attempted for iron-ore sintering. The emission control of $\mathrm{NO}_{x}$ is also anticipated by substituting such resources for coke breeze.

Previous studies ${ }^{2,3)}$ have pointed out that the use of scrap and mill scale reduces productivity. But the reason for this reduction has not clarified.

In the present research, the effects of utilizing MIRs on the sintering process were examined by plant tests at the $100 \mathrm{~m}^{2}$ sintering plant of Nakayama Steel using two kinds of MIRs, both of which were different from that used in the previous studies. ${ }^{2,3)}$ The reason for the decrease in productivity was also studied by conducting a permeability measurement of the sintering bed and a sintercake analysis.

\section{Experimental}

\subsection{Metallic Iron Resources Used}

In this investigation two kinds of MIRs were used. MIR-A is a partially-reduced iron ore containing about 35 mass \% metallic iron, and MIR-B is a material magnetically recovered from slag containing about 55 mass $\%$ metallic iron. Those chemical compositions are listed in Table 1.

We intended a plant test with MIR-A to clarify the effects of metallic iron on sintering, especially on the permeability of the sintering bed; and another one with MIR-B to discuss the influence of the kind of MIR.

\subsection{Blends of the Sinter Mix and Conditions of Plant Test}

In the plant test in MIR-A, the content of MIR-A in the sinter mix was set at the three levels of 0,10 and 20 mass $\%$. To satisfy constant $\mathrm{SiO}_{2}$ content $(=4.9$ mass $\%)$ and constant basicity $\left(\mathrm{CaO} / \mathrm{SiO}_{2}=2.25\right)$ in sinter product, MIR-A was substituted for Bailadila (an Indian ore containing almost the same $\mathrm{SiO}_{2}$ content as MIR-A) under constant contents of limestone and Ni-slag in the sinter mix. The $\mathrm{Al}_{2} \mathrm{O}_{3}$ and $\mathrm{MgO}$ contents changed to some extent, as shown in Table 2.

The plant test was 6 days long. The MIR-A increased from 0 to 20 by 10 mass $\%$ in the first 3 days; decreased reversely in the latter, as shown in MIR-A of Fig. 2.

\subsection{Restrictions on Plant Test}

The $\mathrm{FeO}$ in sinter was to be made constant in the operation by the following manner. When the MIR-A content changed, the amount of coke breeze was also adjusted to keep the exothermic value constant. FeO deviations were adjusted by referring to continuous information from a magnetic FeO-meter, which was corrected by chemical analysis once a day.

\subsection{Methods of Extra Measurements}

Some extra measurements were conducted during the plant test, which are listed in Table 3.

In the heat pattern measurements or the pressure measurements, four thermocouples or probes were 
Table 1. Chemical compositions and mean sizes of materials used.

\begin{tabular}{ccccccccc}
\hline Materials & $\begin{array}{c}\mathrm{T} . \mathrm{Fe} \\
(\mathrm{mass} \%)\end{array}$ & $\begin{array}{c}\mathrm{M} . \mathrm{Fe} \\
(\mathrm{mass} \%)\end{array}$ & $\begin{array}{c}\mathrm{FeO} \\
(\mathrm{mass} \%)\end{array}$ & $\begin{array}{c}\mathrm{SiO}_{2} \\
(\mathrm{mass} \%)\end{array}$ & $\begin{array}{c}\mathrm{Al}_{2} \mathrm{O}_{3} \\
(\mathrm{mass} \%)\end{array}$ & $\begin{array}{c}\mathrm{CaO} \\
(\mathrm{mass} \%)\end{array}$ & $\begin{array}{c}\mathrm{MgO} \\
(\mathrm{mass} \%)\end{array}$ & $\begin{array}{c}\mathrm{MS} \\
(\mathrm{mm})\end{array}$ \\
\hline MIR-A & 78.7 & 35.2 & 50.1 & 2.3 & 1.8 & 0.1 & 0.2 & 1.5 \\
MIR-B & 65.8 & 54.9 & 13.0 & 3.4 & 2.2 & 6.8 & - & 2.7 \\
\hline
\end{tabular}

Table 2. Ore blend conditions and aimed chemical composition of sinter products. (mass \%)

\begin{tabular}{|c|c|c|c|}
\hline Test No. & 1 & 2 & 3 \\
\hline MIR-A & 0.0 & 10.0 & 20.0 \\
\hline Bailadila, F & 40.0 & 30.0 & 20.0 \\
\hline Rio Doce, F & \multicolumn{3}{|c|}{10.0} \\
\hline Hamersley, F & \multicolumn{3}{|c|}{31.2} \\
\hline Hamersley, LF & \multicolumn{3}{|c|}{8.0} \\
\hline Scale & \multirow{2}{*}{\multicolumn{3}{|c|}{$\begin{array}{r}10.0 \\
2.0\end{array}$}} \\
\hline BF dust & & & \\
\hline Ni slag & \multicolumn{3}{|c|}{2.7} \\
\hline Limestone & \multicolumn{3}{|c|}{14.9} \\
\hline Burnt lime & \multicolumn{3}{|c|}{1.2} \\
\hline Total & \multicolumn{3}{|c|}{100} \\
\hline T.Fe & 55.4 & 56.6 & 57.9 \\
\hline $\mathrm{SiO}_{2}$ & 4.9 & 4.9 & 4.9 \\
\hline $\mathrm{C} / \mathrm{S}(-)$ & 2.3 & 2.3 & 2.3 \\
\hline $\mathrm{Al}_{2} \mathrm{O}_{3}$ & 1.7 & 1.6 & 1.6 \\
\hline $\mathrm{MgO}$ & 1.1 & 1.2 & 1.2 \\
\hline $\mathrm{TiO}_{2}$ & 0.1 & 0.1 & 0.1 \\
\hline
\end{tabular}

F: sinter feed, LF: under screen of lamp ore.

Table 3. Special measurements of the plant test.

(1) Heat pattern in the bed

(2) Pressure pattern in the bed

(3) Segregation of chemical components in the bed

(4) Sintercake sampling and its CT measurement

(5) Chemical compositions and qualities of sinter

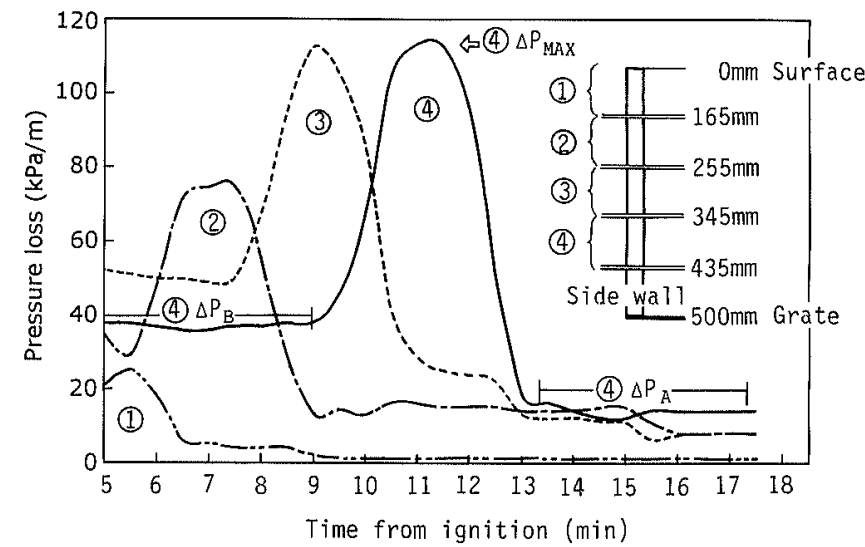

Fig. 1. Example of differential pressures in each layer in the sintering bed.

$165-255 \mathrm{~mm}, 255-345 \mathrm{~mm}$ and $345-435 \mathrm{~mm}$ layers from the bed surface.

In order to get information on the vertical segregation of MIR-A, core samples of the sinter mix were taken with a screw sampler of $100 \mathrm{~mm}$ diameter from the bed between the charging apparatus and the ignition furnace.

Sintercakes of 0 and 20 mass \% MIR-A were sampled to obtain their cross-sectional images with use of X-ray CT. ${ }^{4)}$

Chemical composition and qualities such as TI (Tumbler Index), RDI (Reduction Degradation Index) and JIS-RI (Reducibility Index in JIS) of sinter were measured by the standard methods in Japan. ${ }^{5)}$

\section{Results}

\subsection{Trends of Operational Data}

Figure 2 shows the trends of operational data. Table 4 contains the average values calculated from the data for the each level of MIR-A content. The averaging in Table 4 is reasonable because changes of data in the first three days when the MIR-A increased well coincided with those in the latter when the MIR-A decreased.

The main operational changes obtained were as follows. With increasing MIR-A from 0 to 20 mass $\%$ :

- Size of the dry and wet quasi-particles of the sinter mix decreased by $0.4 \mathrm{~mm}$.

- The product yield decreased by $3.3 \%$.

- The production rate decreased by $21 \mathrm{t} / \mathrm{h}$ due to the yield decrease and the permeability deterioration. The latter can be indicated by the decrease of gas flow rate (measured at the entrance of the main blower) by $400 \mathrm{Nm}^{3} / \mathrm{min}$.

- In the sinter qualities, neither RDI nor TI was significantly changed. JIS-RI showed a tendency to im- 


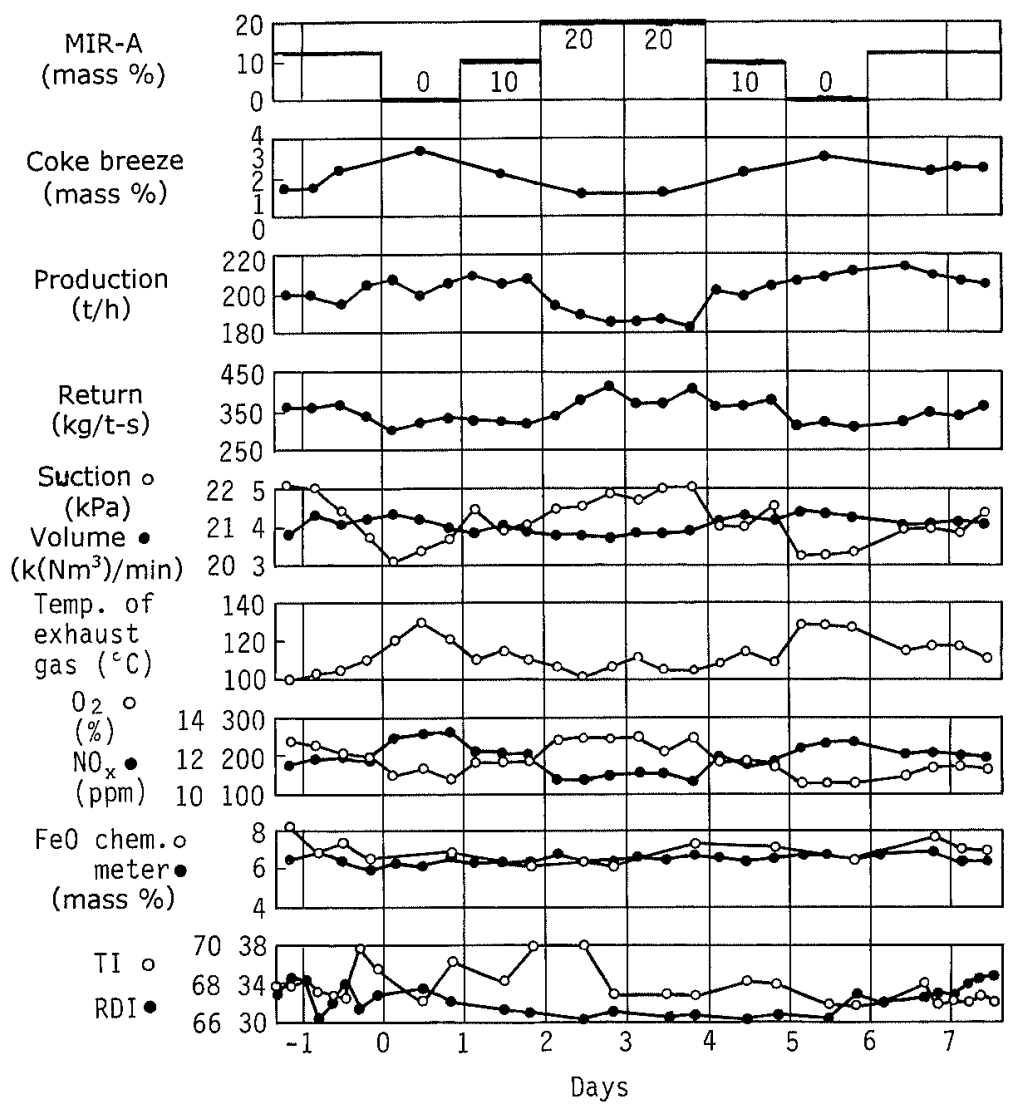

Fig. 2. Trends of the plant test on MIR-A.

Table 4. Plant test results with MIR-A.

\begin{tabular}{|c|c|c|c|c|c|c|}
\hline \multicolumn{2}{|c|}{ MIR-A content } & & nass\%) & 0 & 10 & 20 \\
\hline 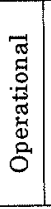 & $\begin{array}{l}\text { Productivity } \\
\text { Coke content } \\
\text { Product yield } \\
\text { Suction } \\
\text { pressure } \\
\text { Gas flow rate }\end{array}$ & $\begin{array}{l}\mathrm{t} / \mathrm{h}) \\
(\mathrm{mas} \\
(\%) \\
(\mathrm{kPa}) \\
\left(\mathrm{Nm}^{3}\right. \\
\left(\mathrm{Nm}^{3}\right. \\
\left(\mathrm{Nm}^{3}\right.\end{array}$ & 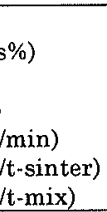 & \begin{tabular}{|c|}
209 \\
3.3 \\
76 \\
20.4 \\
4283 \\
1230 \\
885 \\
\end{tabular} & \begin{tabular}{|l|}
207 \\
2.2 \\
74 \\
21.3 \\
4196 \\
1216 \\
853 \\
\end{tabular} & $\begin{array}{c}188 \\
1.2 \\
73 \\
21.9 \\
3876 \\
1237 \\
853 \\
\end{array}$ \\
\hline \multicolumn{2}{|c|}{ 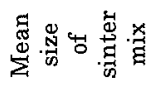 } & $\begin{array}{l}\text { Dry } \\
\text { Wet }\end{array}$ & $\begin{array}{l}(\mathrm{mm}) \\
(\mathrm{mm})\end{array}$ & $\begin{array}{l}2.35 \\
3.09\end{array}$ & $\begin{array}{l}2.29 \\
3.04\end{array}$ & $\begin{array}{l}1.93 \\
2.64\end{array}$ \\
\hline 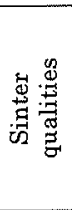 & $\begin{array}{l}\mathrm{SiO} 2 \\
\mathrm{Al} 2 \mathrm{O} 3 \\
\mathrm{MgO} \\
\mathrm{FeO} \\
\mathrm{TI} \\
\mathrm{RDI} \\
\mathrm{RI} \\
\end{array}$ & & $\begin{array}{l}\text { (mass\%) } \\
(\text { mass\%) } \\
(\text { mass\%) } \\
(\text { mass\%) } \\
(-) \\
(-) \\
(-)\end{array}$ & \begin{tabular}{|l|}
5.0 \\
1.84 \\
1.35 \\
6.8 \\
67.7 \\
31.8 \\
72.9 \\
\end{tabular} & \begin{tabular}{c|}
4.9 \\
1.76 \\
1.42 \\
6.7 \\
69.2 \\
31.4 \\
76.9 \\
\end{tabular} & $\begin{array}{c}4.8 \\
1.51 \\
1.56 \\
6.9 \\
68.3 \\
31.7 \\
75.9 \\
\end{array}$ \\
\hline \multicolumn{2}{|l|}{$\begin{array}{l}\text { SOx } \\
\text { NOx }\end{array}$} & & $\begin{array}{l}(\mathrm{ppm}) \\
(\mathrm{ppm})\end{array}$ & $\begin{array}{l}174 \\
247\end{array}$ & $\begin{array}{l}121 \\
194\end{array}$ & $\begin{array}{c}77 \\
147\end{array}$ \\
\hline 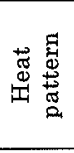 & \multicolumn{3}{|c|}{$\begin{array}{ll}\text { Maximum } & \left({ }^{\circ} \mathrm{C}\right) \\
\text { temperature } & \\
\text { High temperature } & (\min ) \\
\text { retention } & \\
\text { time }\left(>1100^{\circ} \mathrm{C}\right) & \\
\end{array}$} & 1298 & 1274 & 1269 \\
\hline
\end{tabular}

prove.

- The emission of $\mathrm{NO}_{x}$ and $\mathrm{SO}_{x}$ was suppressed by 100 and $97 \mathrm{ppm}$, respectively.

- In the constant-FeO condition employed, the effective ratio of MIR-A to coke breeze was 0.81 from the exothermic point of view.

\subsection{Factor Analysis of the Productivity Decrease}

Factors related to the productivity are the following three:

(1) Gas flow rate affected by the permeability of the sinter bed

(2) Gas volume required for the unit sintercake

(3) Product yield

The first and second factors affect the sintering speed, and the third one is representative of the conversion ratio of sintercake to sinter product.

In this plant test, the productivity decreased by $1.1 \mathrm{t} / \mathrm{h}$ with a 1 mass $\%$ increase of MIR-A. From the factor analysis on the above-mentioned three factors, as shown in Table 5, the productivity decrease was mainly due to permeability deterioration and yield decrease; especially the former resulted in $68 \%$ of the total decrease.

\subsection{Measurements of Segregation in the Bed, Differ- ential Pressure and Sintercake Structure}

In order to determine the cause of the permeability deterioration and the yield decrease, some of the extra measurements were made. The results obtained are as follows:

\subsubsection{Permeability Analysis of the Sintering Bed}

Figure 3 shows changes of the averaged pressure loss in the wet and combustion and sintercake zones in case of increasing MIR-A content. Though some increases were observed in the all zones, it was significant in the sintercake zone. The change of the pressure loss of the sintercake zone in the vertical direction of the bed height is shown in Fig. 4, revealing remarkable increase in the lower layer.

The results of heat pattern measurements, that neither the maximum temperature nor the high temperature retention time in the sintering bed showed significant changes, as shown in Table 4 , denied the increase of 
Table 5. Factor analysis on the productivity reduction.

\begin{tabular}{lllr}
\hline \multicolumn{1}{c}{ Factor } & \multicolumn{2}{c}{$\begin{array}{c}\text { Change per } \\
1 \text { mass\% of }\end{array}$} & \multicolumn{2}{c}{$\begin{array}{c}\text { Productivity } \\
\text { change } \\
\text { MIR-A }\end{array}$} & $(\mathrm{t} / \mathrm{h})$ & $(\%)$ \\
\hline $\begin{array}{lllr}\text { Yield decrease } \\
\text { Gas required for the unit }\end{array}$ & $0.17 \%$ & -0.46 & 32 \\
$\quad-1.6 \mathrm{Nm}^{3} / \mathrm{t}$ & +0.37 & - \\
$\begin{array}{l}\text { sintercake } \\
\text { Gas flow rate }\end{array}$ & $-20 \mathrm{Nm}^{3} / \mathrm{min}$ & -0.99 & 68 \\
Total & & -1.1 & 100 \\
\hline
\end{tabular}

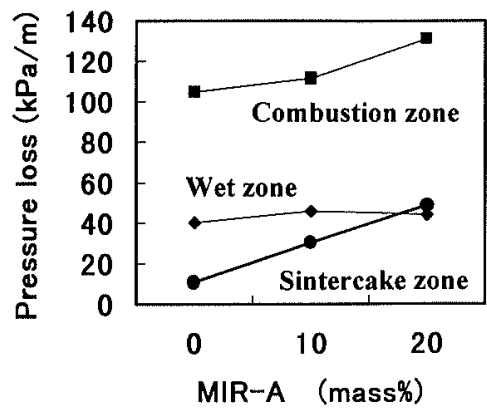

Fig. 3. Changes in pressure loss of each zone with increasing MIR-A content. Averaged frorn 165 to $435 \mathrm{~mm}$ in the bed.

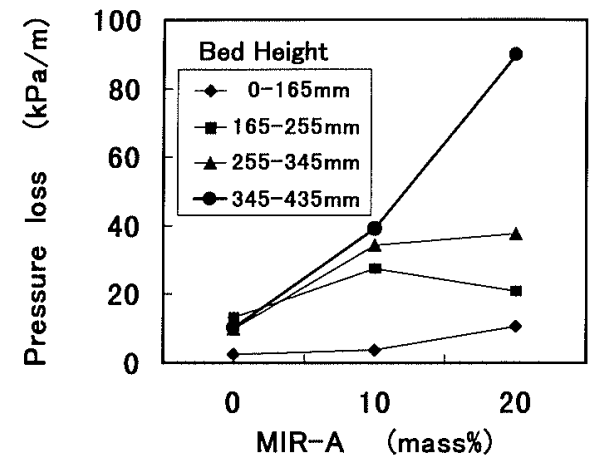

Fig. 4. Change of pressure loss of sinter zone depending on location in the bed.

viscous resistance of gas flow. Therefore, we thought that the deterioration of the permeability was due to the change in pore structure of sintercake.

\subsubsection{Analysis of Sintercake Structure}

In order to confirm the structural change of sintercake, sintercake samples were taken and analyzed by X-ray CT. The cross-sectional images of samples of 0 mass $\%$ MIR-A and 20 mass\% MIR-A, as shown in Fig. 5, revealed the formation of a very dense layer in the lower $100 \mathrm{~mm}$ zone in the sample of 20 mass $\%$ MIR-A. The vertical porosity distribution in the sintercake calculated from the CT images is shown in Fig. 6. In the case of 20 mass $\%$ MIR-A, the porosity decreased rapidly toward the bottom of the bed, and reached to a very small value of $20 \%$.

It was proven that the permeability deterioration and the consequent productivity decrease were mainly caused by a decrease in porosity in the lower part of sintercake.

3.3.3. Segregation of Chemical Composition in the Bed A few bed samplings were conducted to check the

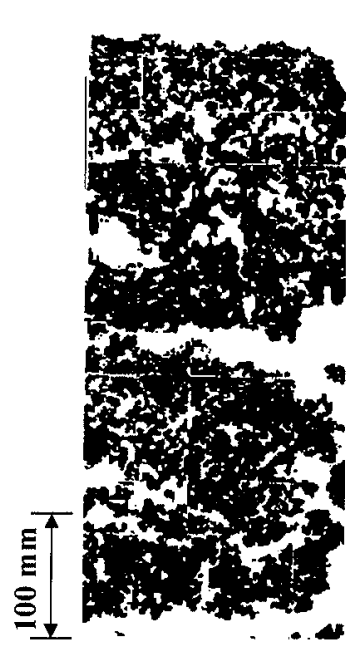

(a) MIR-A $=0$ mass $\%$

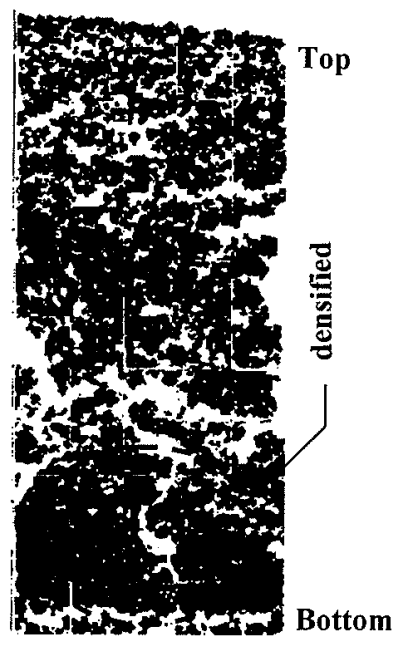

(b) MIR-A $=20$ mass $\%$
Black : matrix, white : pore

Fig. 5. CT images of sintercake in the case of (a) MIR-A= 0 mass $\%$, (b) MIR-A $=20$ mass $\%$.

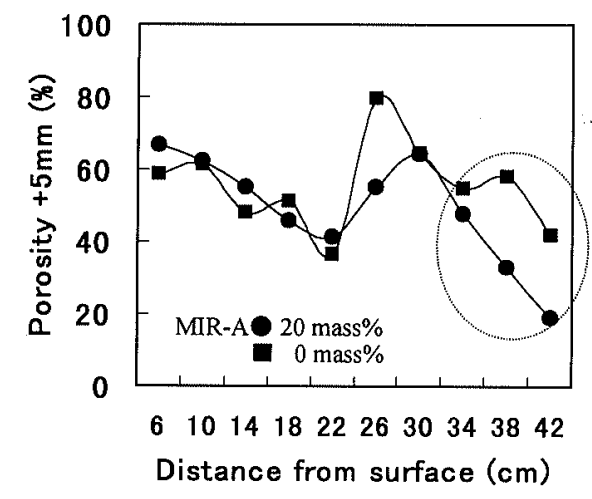

Fig. 6. Comparison of porosity distribution of 0 and 20 mass $\%$ MIR-A.

possibility if the pore shrinkage of the lower part of sintercake was caused by chemical or materials segregation in the vertical direction of the sintering bed.

No segregation of M.Fe (Metallic Iron) content derived from MIR-A was statistically recognized, as shown in Fig. 7(a), as well as $\mathrm{CaO}$ and $\mathrm{FC}$ (Free Carbon) in Figs. 7(b) and 7(c).

\section{Discussion}

\subsection{Permeability Deterioration}

Three possible factors of the decrease in porosity, such as (1) pore remaining after coke combustion, (2) sintering temperature and (3) melt volume, are discussed.

Fujimoto $e t a l{ }^{2)}$ tried to use chips of can scrap on the sintering and found that the productivity decreased. They thought that the reason was the reduction in the amount of pores remaining after coke combustion by substitution of coke breeze to the chips. Figure 8 shows the increase in porosity after heating $\left(\Delta P_{\text {ah }}\right)$ estimated from the data on the chemical segregation of free carbon and $\mathrm{CaO}$, according to the following equation: 


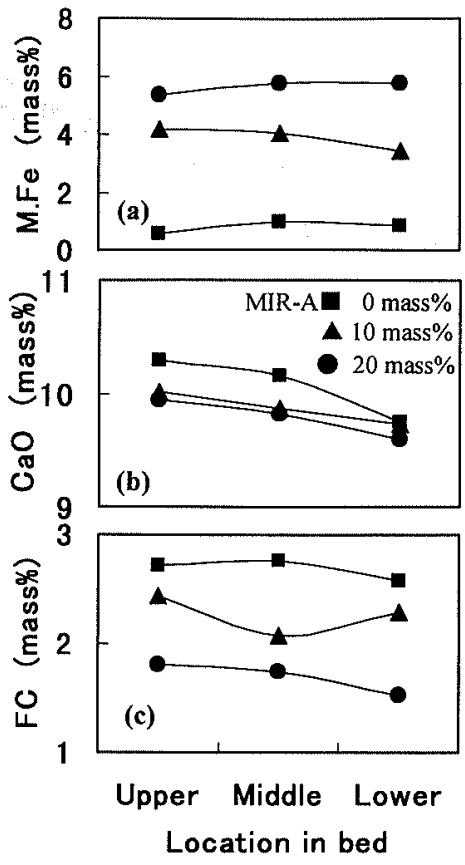

Fig. 7. Change of (a) M.Fe, (b) $\mathrm{CaO}$ and (c) FC (Free Carbon) segregation in the bed due to MIR-A content.

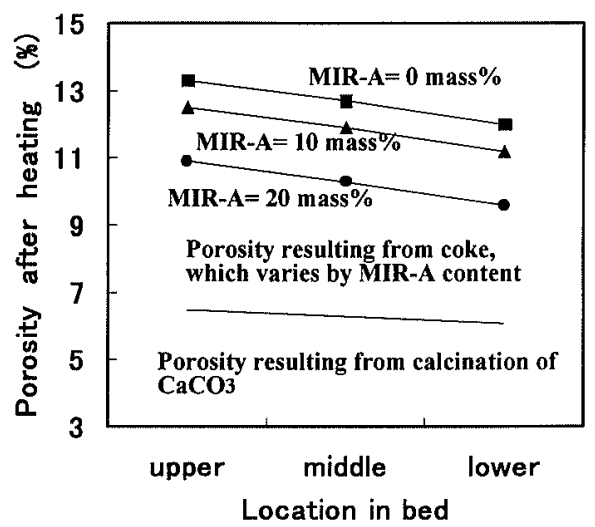

Fig. 8. Change of porosity after heating due to MIR-A content.

$$
\begin{aligned}
\Delta P_{\mathrm{ah}}= & (F C / 100)\left(\rho_{\text {cake }} / \rho_{\text {mix }}\right) \\
& +(L / 100)\left(\left(\rho_{\mathrm{CaCO}_{3}}-\rho_{\mathrm{CaO}}\right) / \rho_{\text {mix }}\right)
\end{aligned}
$$

where $F C$ and $L$ are mass percentage of coke and limestone in the mix; $\rho_{\text {coke }}, \rho_{\mathrm{CaCO}_{3}}, \rho_{\mathrm{CaO}}$ and $\rho_{\text {mix }}$ are the specific gravity of coke, limestone, lime and the sinter $\operatorname{mix}\left(\mathrm{kg} / \mathrm{m}^{3}\right)$. As the after-heating porosity decreases with increase of MIR-A, the mechanism pointed out by Fujimoto et al. can certainly contribute to some extent to the permeability deterioration. However, it is insufficient to explain the remarkable densification of sintercake at the lower layer by increasing MIR-A.

Increase in the sintering temperature could not be the cause; because the $\mathrm{FeO}$ was controlled constant, and the consequent heat pattern measured did not change significantly.

We think a possible reason for the densification at the lower layer as follows: When the concentration of

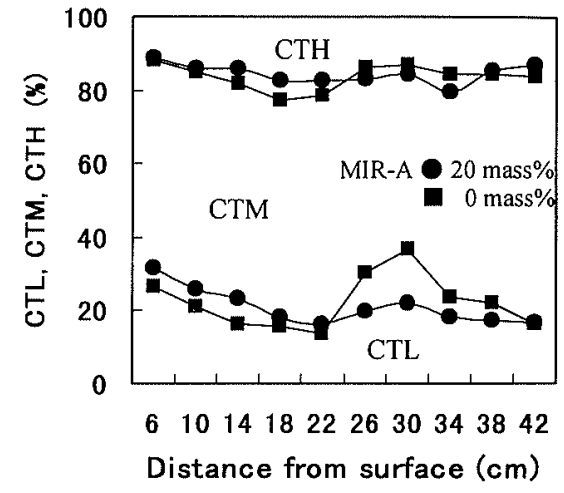

Fig. 9. Comparison of CT-value (CTL, CTM, CTH) distribution of 0 and 20 mass $\%$ MIR-A.

CTL: unsintered part of matrix, CTM: properly-sintered part, $\mathrm{CTH}$ : excess-sintered part, CTL + CTM + $\mathrm{CTH}=100 \%$ of matrix.

metallic iron is constant, the larger particles oxidize to be $\mathrm{FeO}$ melt* more heterogeneously. As Nakano et al. ${ }^{6)}$ reported in case of limestone, heterogeneous melt must move more freely to contacting points of particles without fixed to the surface of unmelted particles, resulting in the sintercake of higher density than homogeneous melt. This reason is applicable to the present case of no MIR-A concentration in the lower layer since larger particles segregate there.

\subsection{Deterioration of Product Yield}

Product yield decreased by about $3.3 \%$ with a 20 mass \% increase in MIR-A. The yield decrease is one of the dominant factors for productivity decreasing. The cause of the yield decrease is considered as follows:

Heat patterns and chemical compositions such as $\mathrm{FeO},{ }^{7)} \mathrm{Al}_{2} \mathrm{O}_{3}$ and $\mathrm{MgO}^{8)}$ which influence the sintercake strength were checked in Table 4. However, neither worsened in the present case. The Tumbler Index, which seems to relate to sintercake strength, did not decrease.

A phenomenon already pointed out by Kasai et al., ${ }^{9}$ Inazumi et al. ${ }^{10)}$ and Nakano et al. ${ }^{11)}$ is that an excessively-melted part causes some unsintered parts below it by blocking the air flow, resulting in the yield decrease. So, an increase in the area of the unsintered part in the sintercake was checked visually in Figs. 5(a) and 5(b) about cross-sectional CT images and digitally in Fig. 9 about CTL distribution. The CTL represents the percentage of unsintered part classified by X-ray CT after Kasama et al. ${ }^{12)}$ These figures showed no significant difference in the amount of unsintered part (CTL).

When the pallet was pulled out to sample the sintercake of 20 mass $\%$ MIR-A, some unsintered parts were observed above the hearth layer. Since unsintered parts there are likely to be left from CT samples, CT observations sometimes lack the information on the bottom layer. Therefore, we thought the yield decrease derived from these parts, and the above-stated phenomena certainly occurred in the lower layer of 20 mass \% MIR-A, though the CT observation showed no evidence.

\footnotetext{
* Under sintering temperature around $1300^{\circ} \mathrm{C}, \mathrm{FeO}$ can melt as $\mathrm{FeO}-\mathrm{CaO}$ system melt since the melting point of $\mathrm{CaO}-\mathrm{FeO}$ is $1123^{\circ} \mathrm{C}$.
} 


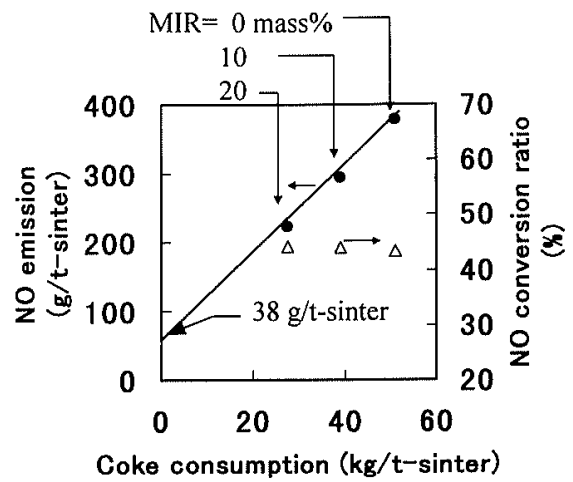

Fig. 10. Plots of NO emission and NO conversion ratio against coke consumption in the plant test on MIR-A.

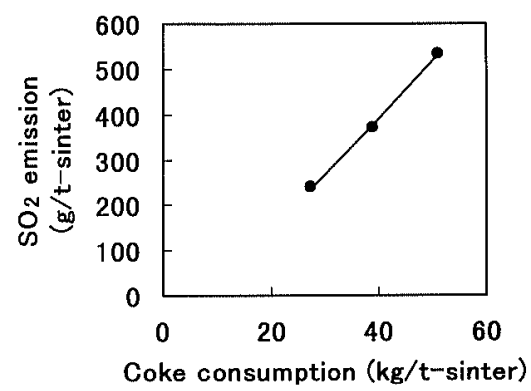

Fig. 11. Plots of $\mathrm{SO}_{2}$ emission against coke consumption in the plant test on MIR-A.

\subsection{Decrease of Emissions of $\mathrm{NO}_{x}$ and $\mathrm{SO}_{x}$}

$\mathrm{NO}_{x}$ and $\mathrm{SO}_{x}$ emission decreased with an increase of MIR-A. Therefore, the use of MIR was useful as an environmental control technology.

The formation mechanism of NO in sintering has already been sufficiently researched. The findings are summarized as follows:

- NO in the exhaust gas is regarded as fuel-NO originated from nitrogen in coke. ${ }^{13)}$

- The conversion ratio of nitrogen in coke to NO depends on the degree of its reduction by $\mathrm{CO}$ in the gas boundary film on the surface of the coke particle. The conversion ratio decreases with an increase in the $\mathrm{CO} / \mathrm{O}_{2}$ ratio in the gas boundary film. ${ }^{14)}$

- The NO conversion ratio is decreased by such as the increase in the coke combustion temperature, ${ }^{15)}$ mini-pellet granulation of coke, ${ }^{16)}$ mixing coke with BOF dust, ${ }^{16)}$ increase in coke breeze consumption ${ }^{17)}$ and the use of quicklime.

Generally, the contribution of thermal- $\mathrm{NO}_{x}$ to total $\mathrm{NO}_{x}$ is small in sintering. ${ }^{13)}$ Assuming the amount of thermal-NO is constant in spite of varying MIR-A contents, it is obtained to be $38 \mathrm{~g} / \mathrm{t}$-sinter by extrapolating the coke consumption to zero in Fig. 10. The approximate coincidence of this value to $60 \mathrm{~g} / \mathrm{t}$-sinter, which Yoshinaga et al. ${ }^{13)}$ obtained by comparison of $\mathrm{Ar}+\mathrm{O}_{2}$ and $\mathrm{N}_{2}+\mathrm{O}_{2}$, confirmed the insignificance of thermal$\mathrm{NO}_{x}$.

The NO conversion ratio obtained was roughly constant at $45 \%$, in any coke consumption. This contradicted a previous result of Yoshikoshi et al. ${ }^{16)}$ obtained from pot tests, that the NO conversion ratio largely
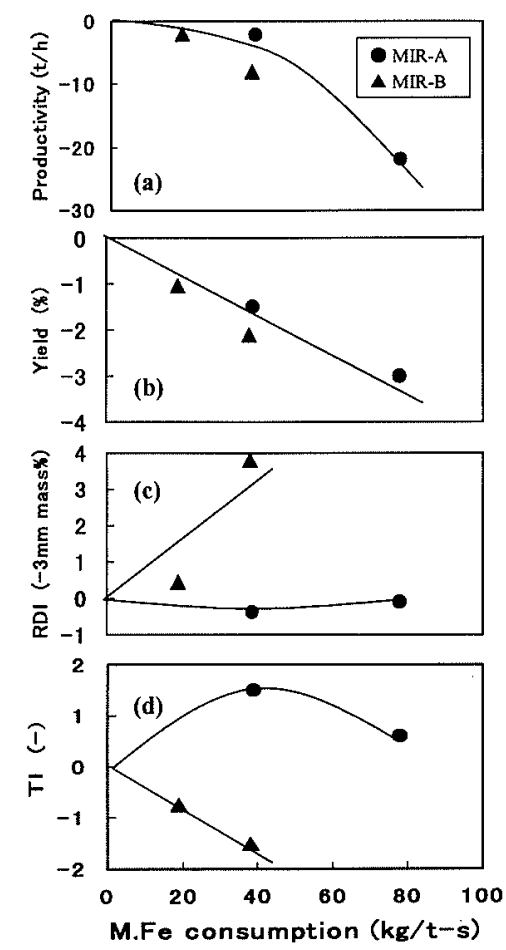

Fig. 12. Difference in (a) productivity, (b) yield, (c) RDI and (d) TI caused by kind of MIR.

decreases from 60 to $20 \%$ with an increase in coke content from 5 to 8 mass \%. This is however thought to be caused by the differences in the total heat input and the consequent temperature in the bed. That is, Yoshikoshi et al. increased the total heat input and raised the bed temperature; on the other hand, we intended to fix them by balancing MIR-A and coke. The important point is whether the bed temperature changes or not, as Hida et al. ${ }^{12)}$ has already pointed out. In this investigation, the NO conversion ratio was approximately constant, as the bed temperature did not significantly change.

Because of the above-mentioned relative insignificance of thermal-NO formation and constancy in the fuel-NO conversion ratio, we have concluded that the decrease in $\mathrm{NO}_{x}$ with use of MIR has been due to the decrease in the amount of fuel- $\mathrm{NO}_{x}$ generated proportionally to the decrease in coke consumption.

Adding comments for $\mathrm{SO}_{x}$, almost the whole quantity of input sulfur from the sinter mix is thought to be oxidized and transferred to the gas phase in the form of $\mathrm{SO}_{x}$. Therefore, the use of MIRs is able to be an effective $\mathrm{SO}_{x}$-suppressive measure because most of the sulfur originates in coke breeze. In this test the $\mathrm{SO}_{2}$ emission was approximately proportional to coke consumption as shown in Fig. 11.

\subsection{Influences of the Kind of MIR}

In order to verify the influence of the kind of MIR, a similar plant test was conducted with MIR-B. The results are plotted in Fig. 12 with the data on MIR-A.

The productivity and yield behaved in the same manner for each MIR, deteriorating against metallic iron consumption, as shown in Figs. 12(a) and 12(b), respectively. 
The agreement of this behavior reinforces the validity of the previously-discussed function of MIRs in sintering.

On the other hand, the qualities showed a dependency on kind, such that MIR-A did not worsen any of them, but MIR-B deteriorated RDI and TI, as shown in Figs. 12(c) and 12(d). We thought it was because MIR-B has high $\mathrm{Al}_{2} \mathrm{O}_{3}$ content and high $\mathrm{CaO}$ content as fine particles of slag. Therefore, other elements such as $\mathrm{Al}_{2} \mathrm{O}_{3}$ and $\mathrm{CaO}$ should be also taken into account on the sinter qualities.

\section{Conclusions}

A plant test on the use of metallic-iron bearing resources in sintering was conducted at Nakayama sintering machine $\left(100 \mathrm{~m}^{2}\right)$, and the following findings were obtained.

(1) The use of MIRs in sintering decreased the productivity due to the deterioration of permeability of sintering bed and yield of product. The permeability deterioration in the bed was mainly derived from that of the sintercake in the lower bed, where the excessive melt was formed to block the airflow. The yield decrease was due to some unsintered portions remaining above the hearth layer.

(2) The qualities depended on the kind of MIR because other elements than metallic iron, such as $\mathrm{Al}_{2} \mathrm{O}_{3}$ and $\mathrm{CaO}$, also affect them.

(3) The emissions of $\mathrm{NO}_{x}$ and $\mathrm{SO}_{x}$ decreased, so the use of MIRs is a useful environmental technology. The decrease of $\mathrm{NO}_{x}$ was due to the decrease of input nitrogen in coke breeze by its substitution for MIRs. $\mathrm{SO}_{x}$ also decreased in the same manner.

\section{REFERENCES}

1) Y. Okuno and M. Fujimoto: US Patent-5,520,719 (3/1996)

2) M. Fujimoto, T. Inazumi and Y. Okuno: CAMP-ISIJ, 7 (1994), 143.

3) K. Takidaira, N. Fujii and Y. Konishi: CAMP-ISIJ, 8 (1995), 913.

4) I. Taguchi and S. Nakamura: Tetsu-to-Hagané, 71 (1985), 1685.

5) A. Shigemi: Iron Making Handbook, Jinchishoin, Tokyo, (1979), 308.

6) M. Nakano, Y. Hosotani, T. Inazumi and S. Kasama: CAMP-ISIJ, 7 (1994), 139.

7) M. Sasaki, T. Enokido, S. Kondou and T. Nakazawa: Tetsu-to-Hagané, $\mathbf{5 9}$ (1973), 1209.

8) M. Sasaki, T. Enokido, S. Kondou and T. Nakazawa: Seitetsu-gihou, 288 (1976), 20.

9) E. Kasai, B. Batcaiman, Y. Omori, N. Sakamoto and A. Kumasaka: ISIJ Int., 31 (1991), 1287.

10) T. Inazumi and S. Kasama: Tetsu-to-Hagané, 78 (1992), 1053.

11) M. Nakano, T. Inazumi, S. Kasama, H. Kaneda, H. Sadaoka and H. Takayasu: Tetsu-to-Hagané, 82 (1996), 111.

12) S. Kasama, T. Inazumi and K. Sato: Proc. the 6th Int. Iron and Steel Cong., Vol. 2, ISIJ, Tokyo, (1990), 118.

13) M. Yoshinaga, K. Nishioka and T. Kubo: Tetsu-to-Hagané, 60 (1974), S22.

14) Y. Hida, M. Sasaki and K. Itou: Tetsu-to-Hagané, 66 (1980), 180.

15) Y. Hida, M. Sasaki, K. Itou and T. Enokido: Tetsu-to-Hagané, 67 (1981), 2625.

16) K. Satou, Y. Sawamura, S. Suzuki, M. Fujimoto and T. Sakurai: Tetsu-lo-Hagané, 64 (1978), S518.

17) H. Yoshikoshi and O. Komatzu: Tetsu-to-Hagané, 63 (1977), S516. 